\title{
TIDD PFBC Demonstration Project
}

\author{
Quarterly Report \\ April 1 - June 30, 1994
}

Mecosing

JUL 24 1937

OSTI

Work Performed Under Contract No.: DE-FC21-89MC24132

For

U.S. Department of Energy

Office of Fossil Energy

Federal Energy Technology Center

Morgantown Site

P.O. Box 880

Morgantown, West Virginia 26507-0880

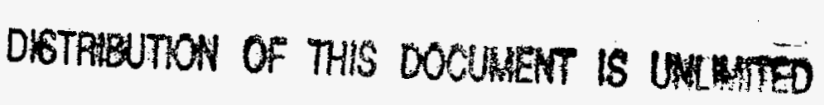
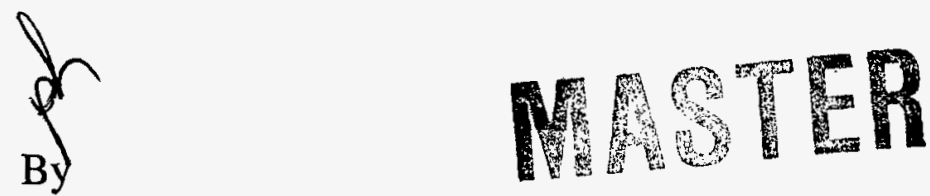

American Electric Power Service Corp.

Columbus, Ohio 43215 


\section{Disclaimer}

This report was prepared as an account of work sponsored by an agency of the United States Government. Neither the United States Government nor any agency thereof, nor any of their employees, makes any warranty, express or implied, or assumes any legal liability or responsibility for the accuracy, completeness, or usefulness of any information, apparatus, product, or process disclosed, or represents that its use would not infringe privately owned rights. Reference herein to any specific commercial product, process, or service by trade name, trademark, manufacturer, or otherwise does not necessarily constitute or imply its endorsement, recommendation, or favoring by the United States Government or any agency thereof. The views and opinions of authors expressed herein do not necessarily state or reflect those of the United States Government or any agency thereof. 


\section{TABLE OF CONTENTS}

PAGE

GLOSSARY OF ACRONYMS AND ABBREVIATIONS USED IN THIS REPORT

1. INTRODUCTION AND SUMMARY

11. DESIGN AND PERMITTING

A. Engineering and Design Division

B. Environmental Engineering Division

C. Testing

III. PROJECT SUPPORT

IV. TIDD PFBC PLANT OPERATIONS

A. Operations

B. Maintenance

V. MANPOWER REPORT

V. COST DATA 


\section{GLOSSARY OF ACRONYMS ÁND ABBREVIATIONS USED IN THIS REPORT}

AARP

AB

AEP

AEPSC

AFC

AFL

$A B B C$

AOP

B\&W

BWCC

BOP

$\mathrm{CB}$

CSWD

CTF

DOE

DRC

E\&SC

ECP

EMP

EOP

EPA

ESP

FAT

\section{Annunciator Alarm Response Procedures}

ASEA Babcock - A business partnership between a subsidiary of ABBC and the Babcock \& Wilcox Company (USA)

American Electric Power Company, Inc.

American Electric Power Service Corporation, a subsidiary of AEP

Approved for Construction

Approved for Layout

ABB Carbon - a subsidiary of ASEA-Brown Boveri (subcontractor)

Abnormal Operating Procedure

The Babcock \& Wilcox Company (subcontractor)

The Babcock \& Wilcox Construction Company (subcontractor)

Balance of Plant

Chicago Bridge and Iron, Inc. (subcontractor)

Cable Schematics Wiring Drawings

Component Test Facility

Department of Energy (United States)

Design Review Committee

Electrical Equipment Service Corporation (subcontractor)

Engineering Control Procedure

Environmental Monitoring Plan

Emergency Operating Procedure

Environmental Protection Agency

Electrostatic Precipitator

Net 90 - Factory Acceptance Test 


\section{GLOSSARY OF ACRONYMS AND ABBREVIATIONS USED IN THIS REPORT}

GSU Generator Step-up Transformer

GT

Gas Turbine

HPT

High Pressure Tubine

HVAC Heating, Ventilating \& Air Conditioning

I\&C Instrumentation \& Control

1OI Initial Operating Instructions

LPT Low Pressure Turbine

MCR Material Control Record

MCS Management Command System

MCC . Motor Control Center

MED Mechanical Engineering Division

NDE Nondestructive Examination

NEMA National Electric Manufacturers Association

NOP Normal Operating Procedure

NOVAA North Ohio Valley Air Authority

NPDES National Pollutant Discharge Elimination System

OEPA Ohio Environmental Protection Agency

OCDO Ohio Coal Development Office - a part of Ohio Department of Development

OPCo Ohio Power Company

PES Plant Electrical Systems

PFBC Pressurized Fluidized Bed Combustion

PMP Project Management Plan

POPS Plant Operations and Performance System 


\section{GLOSSARY OF ACRONYMS AND ABBREVIATIONS USED IN THIS REPORT}

$\begin{array}{ll}\text { ppb } & \text { Parts Per Billion } \\ \text { PTI } & \text { Permit to Instal } \\ \text { PTO } & \text { Permit to Operate } \\ \text { PWHT } & \text { Post Weld Heat Treatment } \\ \text { RDR } & \text { Request for Drawing Revision } \\ \text { RFQ } & \text { Request for Quotation } \\ \text { SD-0 } & \text { System Description (Rev. 0) } \\ \text { SD-1 } & \text { System Description (Rev. 1) } \\ \text { SD-2 } & \text { System Description (Rev. 2) } \\ \text { SD-2.5 } & \text { System Description (Rev. 2.5) } \\ \text { SD-3.0 } & \text { System Description (Final) } \\ \text { SPCC } & \text { Spill Prevention Control \& Countermeasures }\end{array}$

iv 


\section{INTRODUCTION AND SUMMARY}

This is the 29th Technical Progress Report submitted to the Department of Energy in connection with the Cooperative Agreement between the DOE and the Ohio Power Company for the Tidd PFBC Demonstration Plant. This report covers the period from April 1, 1994 to June 30, 1994.

Major activities during this period include:

- The unit operated for 1529 hours on coal, bringing the grand total for coal fire through the end of the quarter to 7847 hours.

- During the quarter, the Tidd Plant set a new record for its longest continuous run on coal - 1079 hours, surpassing its previous record of 740 hours set in June - July of 1992.

- The unit availability for the first half of 1994 was $54.7 \%$.

- There were four gas-turbine starts, eight bed-preheater starts, and six operating periods on coal

- During this quarter, total gross generation was $71,115 \mathrm{MWH}$, the peak unit output for one hour was $59 \mathrm{MWH}$, and the coal consumption was 35,696 tons.

- Fifteen performance tests have been conducted since the start of the fourth year of operation. Eleven of the tests were conducted during the record run during May and June.

- Agreements were finalized with the DOE, Ohio Coal Development Office, and technology vendors for funding of the fourth year of operation of the plant.

Major activities planned for the next period include:

- Continuation of sorbent utilization tests at various bed levels and sulfur retention values.

- Modifications to the plant sorbent preparations system to provide more flexibility in plant prepared sorbent size.

- Testing of different sorbent sizes to investigate the influence of sorbent size on bed dynamics and sulfur capture.

II. DESIGN AND PERMITTING

A. Engineering and Design

\section{Boiler}

Babcock \& Wilcox determined that shielding of the upper rows of the tube bundle would be the best restorable way to reduce the boiler in-bed tube bundle absorption to permit full bed height operation with the limited summer air mass flow capability of the gas turbine compressor. Since it was felt that part load sorbent utilization performance data could readily be extrapolated to full load, a decision was made not to implement this modification. 
In the interest of increasing sorbent utilization, ABB Carbon and Babcock \& Wilcox were commissioned to perform the functional design, layout and detailed design work necessary to install "Zero Stage" cyclones for recirculation of the coarser fraction of the ash elutriated from the bed. The "Zero Stage" cyclones would be installed in the gas stream between the freeboard and the primary cyclone inlets. Ash collected in the cyclones would be recirculated back into the bottom of the bed through dip legs. Rough estimates predict a sorbent demand reduction of approximately 20 - 30\% with this system. In addition, it would permit the testing of low-reactivity fuels, since near complete char burn-out would be achieved due to the increased particle residence time that the system would provide. As of the end of this quarter, the preliminary design and equipment layout were complete, and the detailed cycione, dip leg and gas ducting designs were underway. The basic system design and layout is as follows:

The system would employ two horizontal cyclone separators located outside and atop the boiler roof, each with its own dip leg. Gas from the freeboard would be ducted into the two "Zero Stage" cyclones, and the gas from them would be ducted back into the boiler freeboard and into the seven separate primary cyclone inlets. The dip legs would be routed into the boiler treeboard and down along the boiler sidewalls. The two sidewall evaporator platens would be removed to make space for the dip legs. New dummy tubes would fill in the space voids left to the fore and aft of the dip legs. The iniet and outlet gas ducts as well as the dip legs would all pass through the $2 \mathrm{ft}$. wide boiler maintenance hatch, which spans the entire width of the boiler at the fore/ aft centerline. The hatch cover would be completely removed and new cover plates would fill in the spaces not used by ducts and dip legs.

Firm cost and erection schedule information should be available for the "Zero Stage" cyclone system early in third quarter of 1994. This information, along with an evaluation of the risk/ benefit potential of the system, will be considered in the decision making process as to whether to proceed with their implementation.

\section{Bed Sintering}

Early in this quarter the focus on the cause of the excessive bed sintering shifted from insufficient fuel splitting and poor fuel distribution to a theory that poor bed agitation due to marginal fluidization may be the culprit. In order to test this theory, a decision was made to test finer sorbents. Since the superficial fluidization velocity could not be increased to increase the agitation and mixing, a decision was made to test finer grades of sorbents. The finer sorbents would result in finer beds, which should in-turn result in improved bed particle movement.

Testing was performed during this quarter with finer sorbents that were already crushed and dried by the quarry operators. This material was delivered by bulk pneumatic truck and fed into the plant's 200 ton prepared sorbent silo. The finer sorbents tested were purchased with a minimum amount of directly elutriable fines (-60 mesh), due to concerns about the potential for excessive ash elutriation and overload of the cyclone ash removal system. The sorbent is normally Plum Run Greenfield dolomite prepared on site to a -6 mesh size with approximately $30 \%$ less than 60 mesh. The finer gradation sorbents tested this quarter included the following:

Minus 12 Mesh National Lime Carey dolomite with less than 10\% minus 60 mesh fines Minus 20 Mesh National Lime Carey dolomite with approximately $30 \%$ minus 60 mesh fines 
Minus 12 Mesh Plum Run Greenfield dolomite with less than $10 \%$ minus 60 mesh fines

Testing with these finer sorbents resulted in considerably improved bed conditions including increased heat transfer (up by approximately 10\%) and more even bed and evaporator outlet leg temperature profiles. In addition, testing was performed at 115 in. bed height at the original design bed temperature of $1580 \mathrm{~F}$ with no signs of excessive sintering. Operation had previously been limited to approximately $1540 \mathrm{~F}$ at this bed height due to concerns about sintering. While full bed height was not tested due to air mass flow limitations, the firing rate achieved with the 115 in. bed at $1580 \mathrm{~F}$ was higher than the previous "full load" tests at 142 in. and $1540 \mathrm{~F}$. This was due to a combination of the increased heat transfer and the high bed temperature. This positive experience indicates that the sintering problem can likely be solved through improved bed fluidization. Testing this fall at higher bed heights is expected to verify this finding. At that time, sufficient air mass flow will be available to operate at $142 \mathrm{in}$. bed height with high bed temperatures. It should be noted that the increased heat transfer afforded by the finer bed will likely result in record high unit firing rates and outputs when operating at full bed height.

\section{Gas Turbine}

A noise in the gas turbine exciter caused the unit to be removed from service on $6 / 13 / 94$. Inspection showed that the diode heat sink bolts were hitting the end shield horizontal joint bolts. It is suspected that wear in the reduction gear thrust surfaces allowed the generator to move axially.

The HPT was suspected to be heavily fouled, prior to the outage, because of the increase in HPC pressure ratio and reduction in air flow. A borescope inspection of the HPT confirmed a heavy buildup on the blading. The gas turbine was rolled to speed with the frequency converter to clean the HPT blading with the dry material cleaning system.

The turbine was then removed from service to conduct a planned inspection of the LPT blade roots, LPT inlet guide vane ring, and LPC 1st and 2nd stage stationary guide vanes. Inspection of the LPT blade roots revealed a minor inclusion that was ground and polished out. The LPC had no problems. The LPT inlet guide vane ring was eroded heavily. A new outer ring was purchased from ABBC. The existing inner ring was sent to Central Machine Shop for weld repair. Completion of gas turbine work is expected on $7 / 14 / 94$.

\section{B. Environmental Engineering Division}

- All monthiy and quarterly environmental monitoring reports were filed with the North Ohio Valley Air Authority and Ohio EPA, as required.

- The DOE's Environmental Monitoring Plan (EMP) requires quarterly reports be filed within 60 days of the quarter's end. In compliance with that requirement, the EMP quarterly report for the first quarter (January March), 1994 was submitted to DOE in late May 1994.

- Monitoring of solid, liquid, and gaseous waste streams as required by the operations phase of the EMP was performed throughout the quarter. Results of the monitoring will be included in the third quarter EMP report due to DOE at the end of September 1994. 


\section{Testing}

Fifteen performance tests (Nos. 48 through 62) have been conducted since March 1994, the start of the fourth year of Tidd operation. Eleven of these tests were conducted during the record 1079 hour run during May and June. All tests were conducted with the four point sorbent injection system using various sorbent types and sizes. Pittsburgh \#8 coal was used for all tests.

During the record run significant improvements were made in sorbent utilization by operating with finer grades of sorbent which increased the sorbent surface area, and improved fiuidization and bed mixing. The finer grades of sorbent also allowed testing at full bed temperature of 1580F without significant sinter formation. Tests were conducted with Plum Run Greenfield (P.R.G.) dolomite in top sizes of \#6 mesh and \#12 mesh; and with National Lime Carey (N.L.C.) dolomite in top sizes of \#6 mesh, \#12 mesh, and \#20 mesh. Improvements in unit performance were better than expected.

All tests, during the record run, were conducted at approximately $115^{\mathrm{N}}$ bed level and $90 \%$ sulfur retention with sorbent fed pneumatically. Test results, corrected to $90 \%$ sulfur retention and $1580 \mathrm{~F}$ bed temperature are as follows:

$\begin{array}{ll}\text { Test } 57 & \text { N.L.C. \#6 mesh dolomite } \\ \text { Test } 55 & \text { N.L.C. \#12 mesh dolomite } \\ \text { Test } 58 & \text { N.L.C. \#20 mesh dolomite } \\ \text { Test } 52 & \text { P.R.G. \#6 mesh dolomite } \\ \text { Test } 60 & \text { P.R.G. \#12 mesh dolomite }\end{array}$

$2.17 \mathrm{Ca} / \mathrm{S}$ ratio $1.85 \mathrm{Ca} / \mathrm{S}$ ratio $1.44 \mathrm{Ca} / \mathrm{s}$ ratio $1.91 \mathrm{Ca} / \mathrm{S}$ ratio $1.32 \mathrm{Ca} / \mathrm{S}$ ratio

All of the above tests were conducted at approximately 1580F bed temperature with the exception of Test 52 which was conducted at $1500 \mathrm{~F}$ due to past experience of sintering problems that normally occurs with the \#6 mesh Plum Run dolomite at temperatures above 1520-1540F. The results obtained while operating with the P.R.G. \#12 mesh dolomite correlate to $\mathrm{Ca} / \mathrm{S}$ ratios of approximately 1.5 at $95 \% \mathrm{SR}$, and 1.2 at $90 \%$ SR at full bed height.

For the purpose of comparison, the following are typical results normally obtained while operating with \#6 mesh Plum Run Greenfield dolomite at $115^{\prime \prime}$ bed level adjusted to $90 \%$ sulfur retention and $1580 \mathrm{~F}$ bed temperature: 
Tests with two sorbent feed points

Tests with four sorbent feed points

\section{$2.2 \mathrm{Ca} / \mathrm{S}$ ratio}

$1.9 \mathrm{Ca} / \mathrm{S}$ ratio

A companion of the calcium-to-sulfur molar ratio various sorbent feeds is presented graphically in Figure

1. Additional tests to optimize sorbent sizing are planned for the upcoming test runs.

\section{TIDD PFBC DEMONSTRATION PLANT CAS RATIO VS. BRD LEVEL AT 90\% S.R, 1580F BED TBNP.}

\section{Cus Rutio}

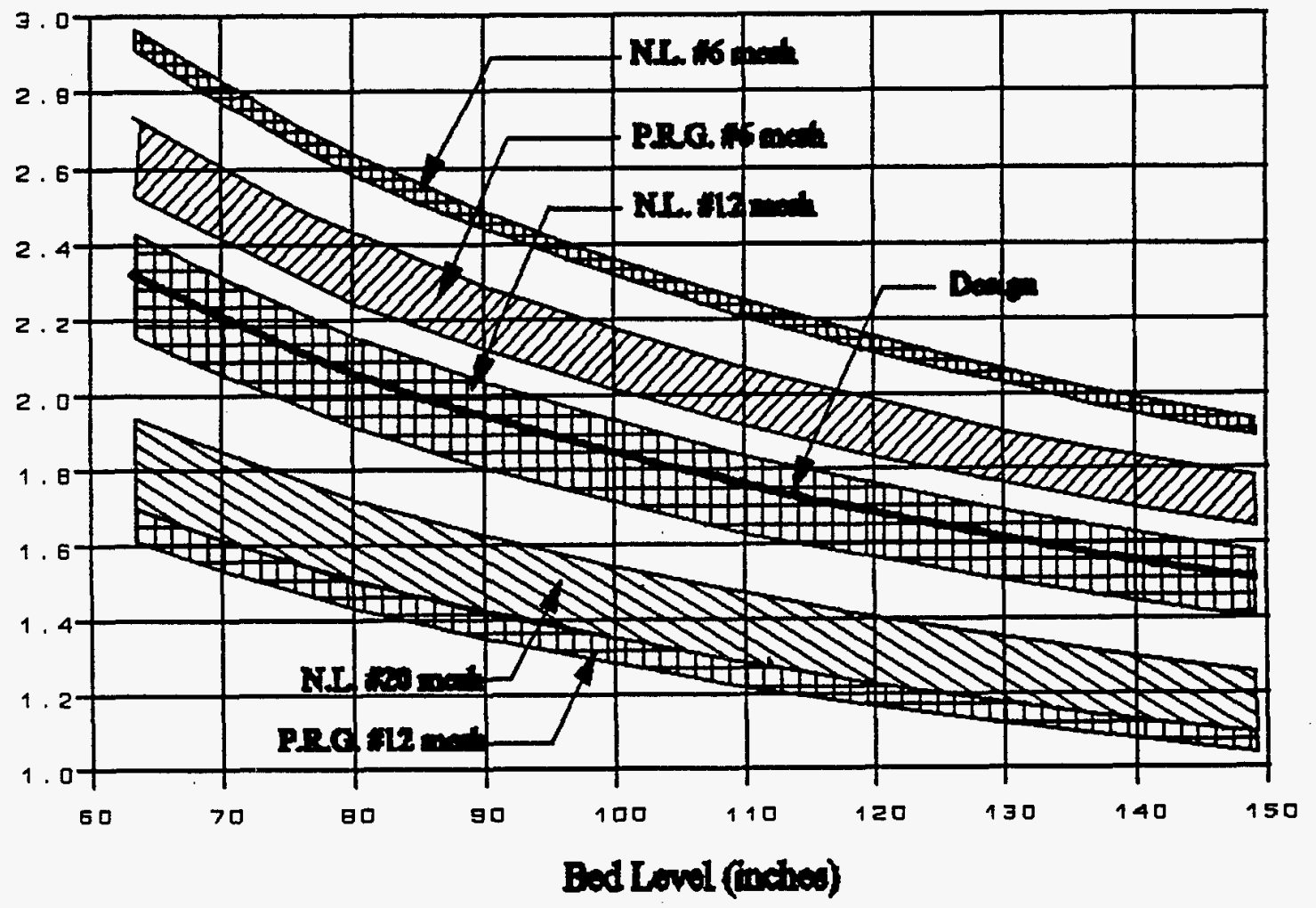

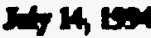




\section{PROJECT SUPPORT}

Major Projects Division continues to process significant purchase requisitions required to support construction or maintenance-related work. Additional activities include identifying changes to segments of the Project Management Plan associated with the extended duration of the Phase III tasks.

\section{OPERATIONS}

The following is a summary of accumulated operating data for the period April 1, 1994 through June 30, 1994:

\begin{tabular}{|c|c||}
\hline \multicolumn{2}{|c|}{ Generation } \\
\hline Steam Tubine & $58283 \mathrm{MWH}$ \\
\hline Gas Turbine & $12872 \mathrm{MWH}$ \\
\hline Total Gross & $71155 \mathrm{MWH}$ \\
\hline Peak Generation tor 1 Hr. & $59 \mathrm{MWH}$ \\
\hline \multicolumn{2}{|c|}{ Operating Time } \\
\hline Total Oil Fire & 7 Hours \\
\hline Total Coal Fire & 1508 Hours \\
\hline \multicolumn{2}{|c|}{ Injection } \\
\hline Total Coal & 35696 Tons \\
\hline Total Sorbent & 28188 KLB \\
\hline
\end{tabular}

The unit was operated for a total of 1529 hours (including gas turbine air warming). There were four gas turbine starts, two bed preheater starts, and two operating periods with coal fire. The peak gross output of $59 \mathrm{MWH}$ was for the period of 2100 - 2200 hours on May 13, 1994. A Tidd PFBC coal fire record run of 1079 hours was achieved during the quarter. The availability of the unit for the first half of 1994 was $54.75 \%$

The Hot Gas Clean Up system was in service for the first coal fire operating period, but was isolated for the second run.

1. Start-Up TD-SU-94-06-01 March 30 - April 19, 1994

The purpose of the startup was to run for at least 30 days for a reliability run and to conduct testing for hazardous air pollutants and to determine the reasons for sintering.

The unit was in service at the beginning of the quarter.

While holding at $115^{\prime \prime}$ to mature the bed a problem developed with the fuel prep system crusher. The crusher tripped several times on high current. The paste tank level was 
extremely low before the problem was traced to low accumulator pressure on the right side of the crusher. After increasing this pressure the crusher system functioned properly.

After the bed had matured bed level was increased to 125 " and bed temperature raised to 1540 degrees to evaluate if these conditions could be maintained without sintering the bed. Within 24 hours signs of sintering were being observed. Six hours later bed level and bed temperature were lowered $\left(115^{n}\right.$ - 1500 degrees) to avoid letting the bed get to a condition from which it would be harder to recover.

The next day bed conditions had improved slightly. Air flow was increased (increasing pressure vessel pressure) to try to determine if higher pressure would have any effect on the sintering of the bed. Bed temperature was also increased at this time from 1500 degrees to 1520 degrees. After only a few hours the signs of sintering were again showing. Air flow was reduced to normal and bed temperature was lowered to 1500 degrees and later to 1480 degrees. Bed level was slowly lowered to $80^{\prime \prime}$ and then raised back to 115 in an attempt to clean out the tube bundle of sinters.

By April 8th, the bed conditions were somewhat improved. Bed level and temperature were held constant at 115", 1500 degrees, $90 \%$ sulfur retention for the next several days to provide steady state conditions for the hazardous air pollutant testing.

A unit performance test was conducted on April 9th.

Hazardous air pollutant testing was set up and conducted by Radian personnel from April 11th through April 15th.

On April 18th a leak developed internal to the combustor on the ceramic lined sorbent injection piping.

The combustor was tripped at 2043 hours on April 18th due to the sorbent piping leak. After cooling the bed the gas turbine was removed from service at 0149 hours on April 19th.

2. Start-Up TD-SU-94-07-01 April 29 - June 16, 1994

The objective of the run was to test the effects of smaller size sorbent on the fluidization of the bed.

During the outage several broken candles were found in the APF and it was decided to isolate HGCU from PFBC for this run, which would allow APF repairs to be made in parallel with unit operations. The fuel nozzles skateboards were moved back to their original position. Orifices were installed in the two outer sorbent injection nozzles to try to balance sorbent flows.

Warming of the combustor was accomplished and the gas turbine was rolled at 0737 hours, paralleled at 0754 hours and air flow established through the combustor at 0802 hours on April 29, 1994. During this air heating period the LPC was dry cleaned using Carboblast.

An oil fire was established at 1309 hours but a combustor trip followed when the vertical separator pressure control valve stuck and popped open causing the vertical separator level 
to go extremely high.

An oil fire was re-established at 1400 hours.

The steam turbine was rolled and paralleled at 2000 hours on April 29th.

A coal fire was initiated at 2038 hours and sorbent injection started at 2210 hours on April 29th.

The anti-skewing control modification for the fuel preparation system crusher which was installed during the outage worked very well. This modification allowed a more uniform paste product to be produced.

Once through boiler operation was achieved at 0046 hours on April 30th.

Bed level was increased to $90^{\prime \prime}$ with bed temperature at 1515 degrees and maintained there while the bed matured. This lower bed level for maturing the bed was to prevent higher fuel flows (possible sintering conditions) while the dense start up bed was present.

On May 1st bed level was increased to $115^{\mathrm{N}}$ and bed temperature was reduced to 1500 degrees. Sulfur retention was maintained at $90 \%$. These conditions were maintained for about one week to confirm that no sinters were being made.

A unit performance test was conducted on May 2nd at the above conditions using Tidd plant prepared Plum Run Greenfield (PRG) sorbent and Pittsburgh \#8 coal.

During this week a few trucks of \#12 National Lime Carey (NLC) sorbent were received as a test to determine if material received this way could be unloaded into the sorbent preparation system storage vessel fast enough to support unit operation. It was confirmed that this could be done.

On May 6 th the south bed ash reinjection vessel outlet plugged off and remained that way for the remainder of the run.

On May 9th the shipments of NLC \#12 sorbent started to arrive on site for a four day test. This material began to be injected to the bed at about 0400 hours on May 10th. A series of unit performance tests at $115^{\mathrm{n}}$ and $90 \%$ sulfur retention with bed temperature at 1500 degrees, 1540 degrees and 1580 degrees were conducted from 1600 hours on May 11th to 1200 hours on May 13th. Bed temperature was reduced to 1500 degrees at 1600 hours on May 13 th.

When the shipments of NLC \#12 sorbent stopped, NLC sorbent was prepared with the sorbent prep system. When this material was introduced into the bed the fluidization started to deteriorate as evidenced by some of the evaporator tube temperatures increasing into alarm and erratic bed temperatures.

A unit performance test was conducted on May 16th. The conditions for the test were, 115" bed level, 1500 degrees bed temperature, 90\% sulfur retention with NLC (Tidd plant prepared). Following this test the bed temperature was increased to 1580 degrees at 0800 hours on May 17th. Bed conditions gradually worsened. Density was on the decrease, five 
evaporator tube temperatures were in high alarm and some of the bed temperatures began to be very erratic indicating fluidization problems. At 1138 hours on May 18th bed temperature was reduced to 1500 degrees.

By May 19th the NLC sorbent was depleted and the unit was operating on PRG sorbent which was prepared on Tidd site. The unit was maintained at $115^{\prime \prime}$ bed level, 1500 degrees bed temperature and $90 \%$ sultur retention until May 23 rd. Bed conditions did not change.

On May 23rd the LPC was dry cleaned with Carboblast in an effort to increase air flow. Air flow had been noticeably reduced for the last week.

At 2200 hours on May 23rd, approximately 75 tons of NLC \#20 sorbent was started into the bed with the sorbent injection system. This short test was to determine if bed level. could be maintained with this smaller size of sorbent feed. Bed ash production was lower but bed level was able to be maintained. Bed temperature distribution and evaporator temperatures improved significantly on May 24th with this material. When this material ran out the bed conditions again started to deteriorate.

Another small delivery (175 tons) of \#20 NLC sorbent was received on May 25th for testing. Again, when this material was introduced into the bed the unstable conditions significantly improved. Bed ash production was estimated to be $4 \mathrm{klbs} / \mathrm{hr}$ and it was decided that the unit could withstand a four day test with this \#20 sorbent.

As was previously seen, when this small delivery of \#20 material was all used and the unit was returned to Tidd plant prepared material the bed conditions worsened.

On May 27th a hydraulic leak developed on \#6 paste pump. The pump was removed from service to repair the leak. With the unstable bed conditions, the removal of this paste pump from service caused very high bed and evaporator tube temperatures on the right side of the boiler. After returning \#6 paste pump to service the bed conditions returned to the previous unstable but maintainable condition.

The unit remained at this condition for the next three days to see if any improvement could be seen. No improvement was observed.

On May 30th the trucked shipments of \#20 NLC sorbent began arriving on site for a four day test. At approximately 0630 hours on May 31st this material started to be injected into the bed. Bed conditions immediately began to improve.

On June 1st bed temperature was increased to 1580 degrees and bed level was lowered to $113^{4}$. Also on June 1st the LPC was Carboblast cleaned (the gas turbine performance was still decreasing).

On June 1st the quarterly stack dust loading test was completed. Unit performance tests and sampling were conducted from 1200 hours on June 1st to 2400 hours on June 3rd.

On June 2nd sulfur retention was increased to $95 \%$, but was lowered back.to $90 \%$ a short time later because of high temperatures in the bed ash removal system. The bed bottom cooling could not maintain adequate cooling of ash with the higher sorbent fiow rate required for $95 \%$ sulfur retention. 
At 1100 hours on June 3rd bed temperature was lowered to 1500 degrees. The problem with high temperatures in the bed ash removal system continued. The smaller size bed material seemed to just flow out of the ash removal system without any pulsing. This caused overheating and subsequent trips on the removal system. The sorbent fines that were remaining in the 500 ton storage vessel were mixed with the paste to reduce the required dry sorbent feed rate to help reduce the amount of bed ash removal required to maintain bed level. Bed temperature was also lowered to 1480 degrees to reduce bed ash production.

On June 5th, while still fighting to keep bed level down, the south bed ash removal system plugged off in the bed bottom area. The north bed ash reinjection vessel was called into service to maintain bed level (bed level had increased to 123"). Efforts to unplug by blowing up through the bed bottom were unsuccesstul. The south removal system was isolated, the pressure in the lockhopper reduced to 25 psi less than the bed bottom pressure and then the isolation valve was opened. This maneuver cleared out the plug and dropped bed level by six inches. Once the south bed ash removal system was unplugged the bed level could be controlled, but temperatures in the removal system were still elevated.

After the bed ash removal system had recovered from the high temperatures, the north bed ash reinjection vessel was emptied back into the bed.

On June 6th the deliveries of PRG \#.12 sorbent started arriving at site, but it was midday on June 7 th before this material made it to the bed.

Installation of the new sorbent prep sizer screen began on June 6th while the unit was being tested with the \#12 PRG sorbent.

Due to the anticipated high ambient temperatures and subsequent lower available air flow, bed level was lowered to $108^{\prime \prime}$ for a series of tests with \#12 PRG sorbent.

On June 8th bed temperature was increased to 1580 degrees and a unit performance test conducted at 108 " with $90 \%$ sulfur retention from 0000 to 1200 hours on June 9th. At 1200 hours sulfur retention was increased to $95 \%$ for a test, but the test was aborted when the increased bed drain flow again presented a problem with high temperature trips of the bed ash removal system.

After the $95 \%$ sulfur retention test was aborted bed level was increased to $115^{\mathrm{n}}$, bed temperature reduced to 1500 degrees and sulfur retention maintained at $90 \%$. A unit performance test was conducted from 0000 to 1200 hours on June 10th at these conditions. At 1200 hours air flow was lowered for a unit performance test to compare the effects of excess air on sulfur retention. This test was not successful, however, due to gas turbine conditions prohibiting achieving the desired conditions. It was identified that the HPT was fouled to the point of restricting the operation of the gas turbine. When air flow was cut without cutting load, the HPC pressure ratio alarm came in.

At 0200 hours on June 10th the drive belts failed on the \#2 vapor extractor for the gas turbine lube oil. The \#1 vapor extractor was placed in service. The belts were replaced on the \#2 vapor extractor. 
On June 10th the differential pressure on the sorbent booster compressor inlet fines filter increased to 160 inches of water. This differential pressure was monitored closely for the remainder of the run. It approached 190 inches before the unit was shut down.

On June 11th the new sorbent prep sizer screen was initially operated. The bed support springs were undersized and the screen did not function properly because of the spring problem. Additional PRG \#12 was ordered to be used until the screen could be adjusted to function well enough to support unit operation.

On June 11th and June 12th 6A coal was test crushed in the fuel prep system. The crusher system could not be adjusted to make an acceptable paste product. While using this paste, \#3 paste pump plugged and was removed from service to clean. Other paste pumps also experienced high differential pressures before the marginal paste in the tank was diluted with \#8 coal paste. Bed level was reduced to $110^{\prime \prime}$ and bed temperature lowered to 1480 degrees during this period of time.

On June 12th a noise was discovered in the gas turbine exciter. A problem was suspected with diode mounting. To prevent further damage it was decided to remove the unit from service.

Unit load was reduced and the steam turbine was removed from service to perform the annual overspeed test. This test was successfully completed and the combustor tripped at 2016 hours on June 13th. The gas turbine was used to cool the bed and then removed from service at 2255 hours on June 13th. The combustor was cooled to approximately $\mathbf{4 0 0}$ degrees in anticipation of dry cleaning of the HPT before opening the combustor.

\section{B. Maintenance}

1. Outage TD-OT-94-06-01 April $19-28,1994$

The unit was shut down due to a leak on the sorbent injection ceramic lined pipe.

Repaired mitred joints of ceramic lined sorbent injection piping.

Replaced the fines filter on the sorbent booster compressor.

Installed orifices on the two outside sorbent nozzles inside of the bed.

Rebuilt sorbent prep system fan inlet vane housing.

Moved tuel injection skateboards back to original position.

Repaired leaks on primary cyclone ash lines in primary ash coolers.

Replaced the primary and secondary cyclone dipleg thermocouples with continuous lead type.

Filled bed ash reinjection vessels with sand and bed material for startup.

Isolated HGCU from PFBC. 
Replaced one of the paste tank level transmitters due to wear.

Installed anti-skewing controls on the fuel prep system crusher.

Replaced the gear boxes on the paste tank agitators to reduce current draw on motors (40\% speed reduction).

Replaced bent shaft on \#5 paste pump HMC valve.

Inspected gas turbine LPT blade roots with video boroscope.

Liquid cleaned gas turbine LPC.

Replaced failed gas turbine HPT shaft speed pickup.

Replaced fourth stage rings on HGCU backpulse compressor.

Revised oiling system on fourth stage of HGCU backpulse compressor.

Replaced the impulse tubing on the APF gas flow meter.

2. Outage TD-OT-94-07-01 Beginning June 13, 1994

The unit was removed from service due to a noise in the gas turbine exciter.

Dry cleaned the gas turbine HPT using Carboblast.

Removed the gas turbine LPT for inspection of blade roots (No indication of root or other cracking).

Removed gas turbine LPT inlet guide vane and made repairs to erosion areas. Replaced outer ring.

Rebuilt 10 bed ash removal system valves.

Inspected south bed ash reinjection vessel for pluggage and filled both vessels with sand and bed material for startup.

Tied HGCU to PFBC.

Added-a-second high ash level probe to APF.

Installed complete detuning system for \#11 primary cyclone.

Repaired 18 tube leaks in steam turbine condenser.

Repaired lube oil leak on \#3 bearing on steam turbine.

Installed new sorbent prep system sizer screen assembly.

Inspected sorbent injection ceramic lined piping. 
Repaired air leaks on splitting air compressor cylinders.

Rebuilt vertical separator level control valve, LCV-U200A.

Rebuilt vertical separator pressure control valve, PCV-B200.

Rebuilt vertical separator pressure control valve, PCV-B200.

Installed "dam" on each of the bed ash removal "L" valves to try to reduce flow through.

Mechanically cleaned all process air distribution pipes.

Inspected and cleaned water side of process air cooler.

Installed tube shields on secondary superheater tubes.

Repaired leaks on primary ash system lines inside of primary ash coolers. 


\section{MANPOWER REPORT}

As of June 30, 1994, AEPSC actual work-hours for the Phase III accounted for $41.8 \%$ of the total budget of 135,098 . Figure 1 represents the budget versus actual work-hours for this phase.

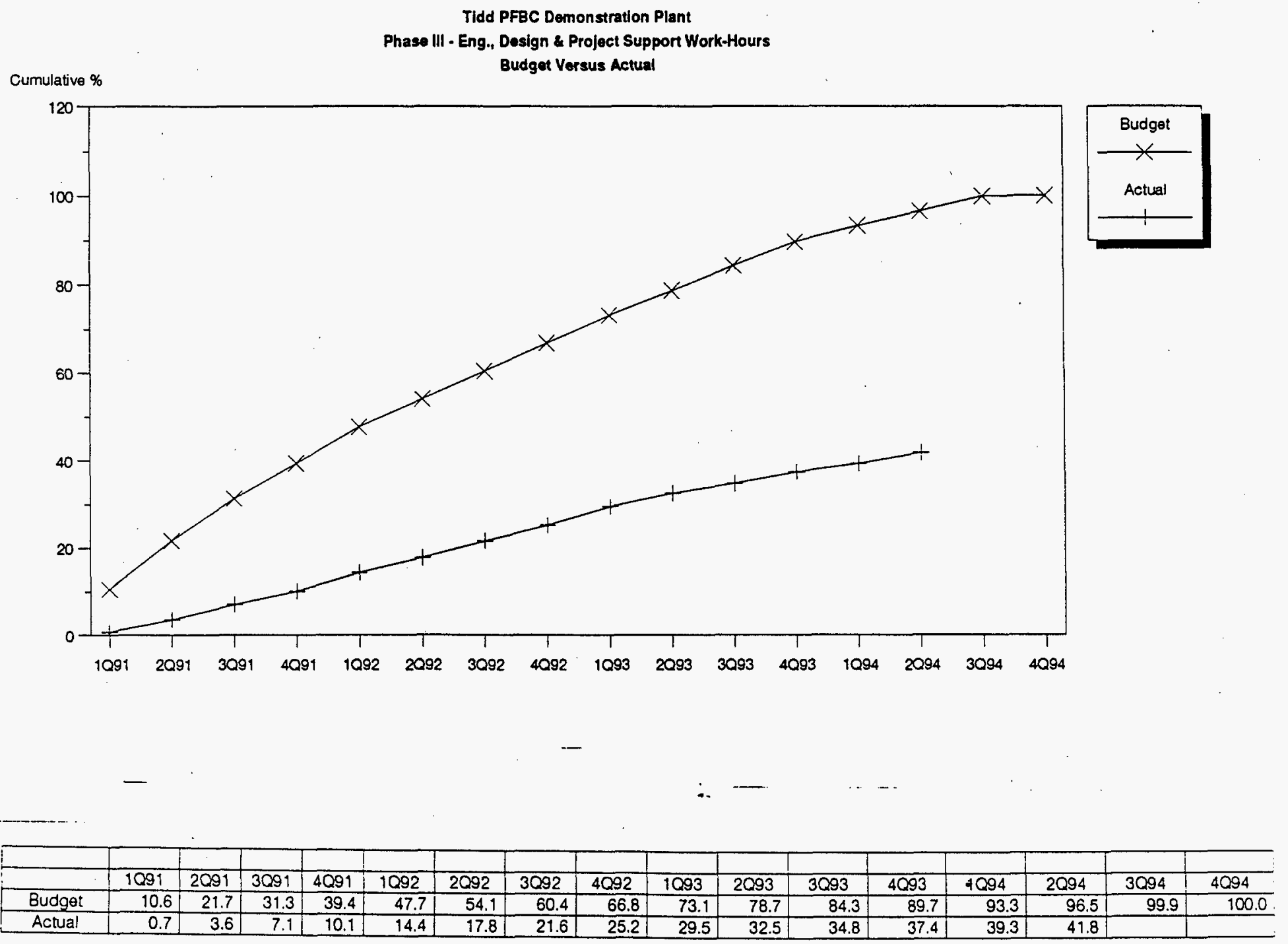


Figure 3 is a projection of the quarterly expenditures for all participants. It also identifies the actual quarterly expenditures through the Second Quarter 1994.

Tldd PFBC Demonstration Plant

Quarterly Expenditures - All Participants Phases I, II \& III

Sin Millions

Forecast versus Actual

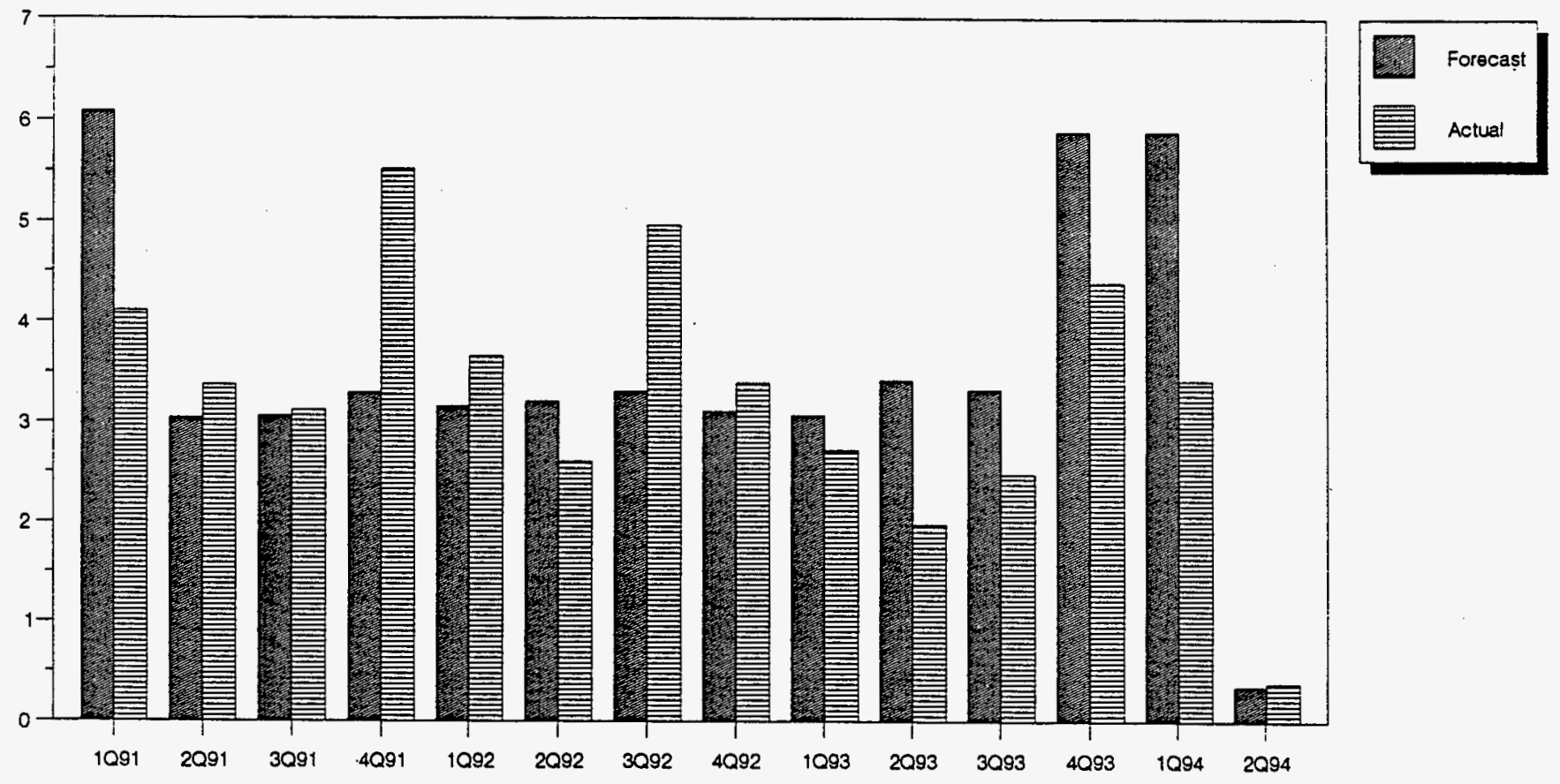

\begin{tabular}{|c|c|c|c|c|c|c|c|c|c|c|c|c|c|c|c|c|}
\hline & (in Millio & & & & & & & & & & & & & & & \\
\hline & Thru 9 & 1091 & 2091 & 3091 & 4091 & 1092 & 2092 & 3092 & 4092 & 1093 & 2093 & 3093 & 4093 & 1094 & 2094 & To-date \\
\hline Forecast & *......" & 6.082 & 3.044 & 3.063 & 3.298 & 3.161 & 3.212 & 3.311 & 3.116 & 3.072 & 3.427 & 3.334 & 5.889 & 5.888 & 0.354 & 193.186 \\
\hline Actual & ...." & 4.107 & 3.373 & 3.121 & 5.521 & 3.659 & 2.603 & 4.967 & 3.402 & 2.721 & 1.979 & 2.478 & 4,397 & 3.423 & 0.384 & 178.823 \\
\hline
\end{tabular}


The following table summarizes the project expenditures as of June 30,1994 , of all participants:

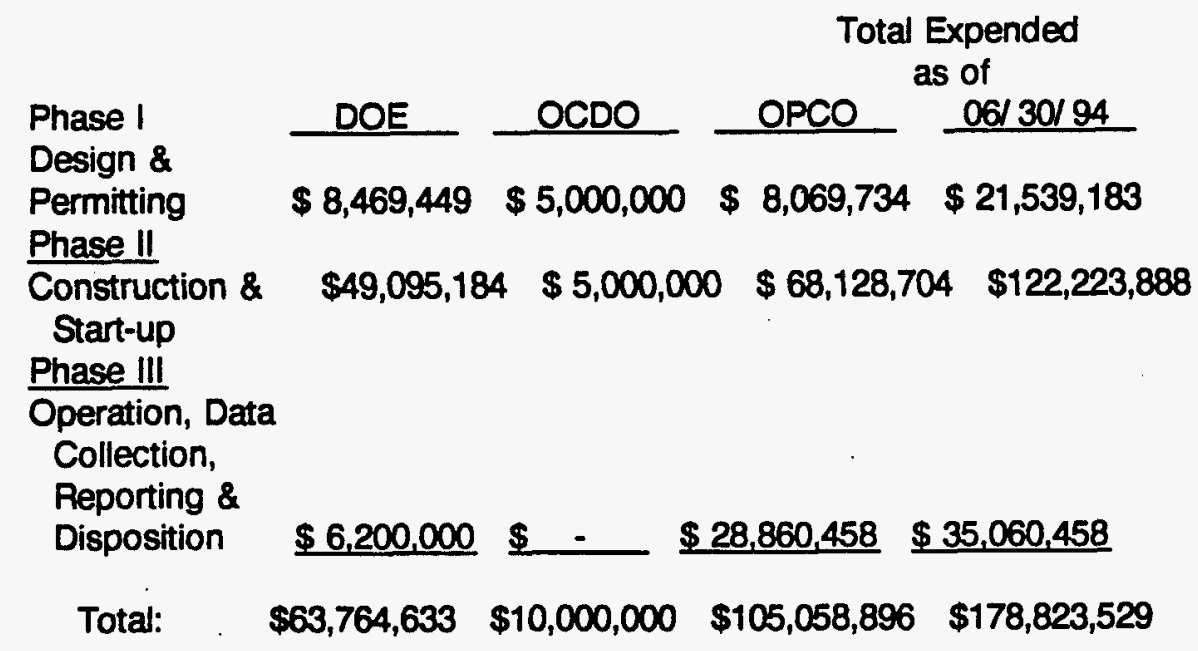


Figure 4 is the Phase III DOE quarterly actual and projected expenditures.

Tidd PFBC Demonstration Plant

Quarterly Expenditures - DOE Share Phase III

$\$$ in Miltions

Forecast versus Actual
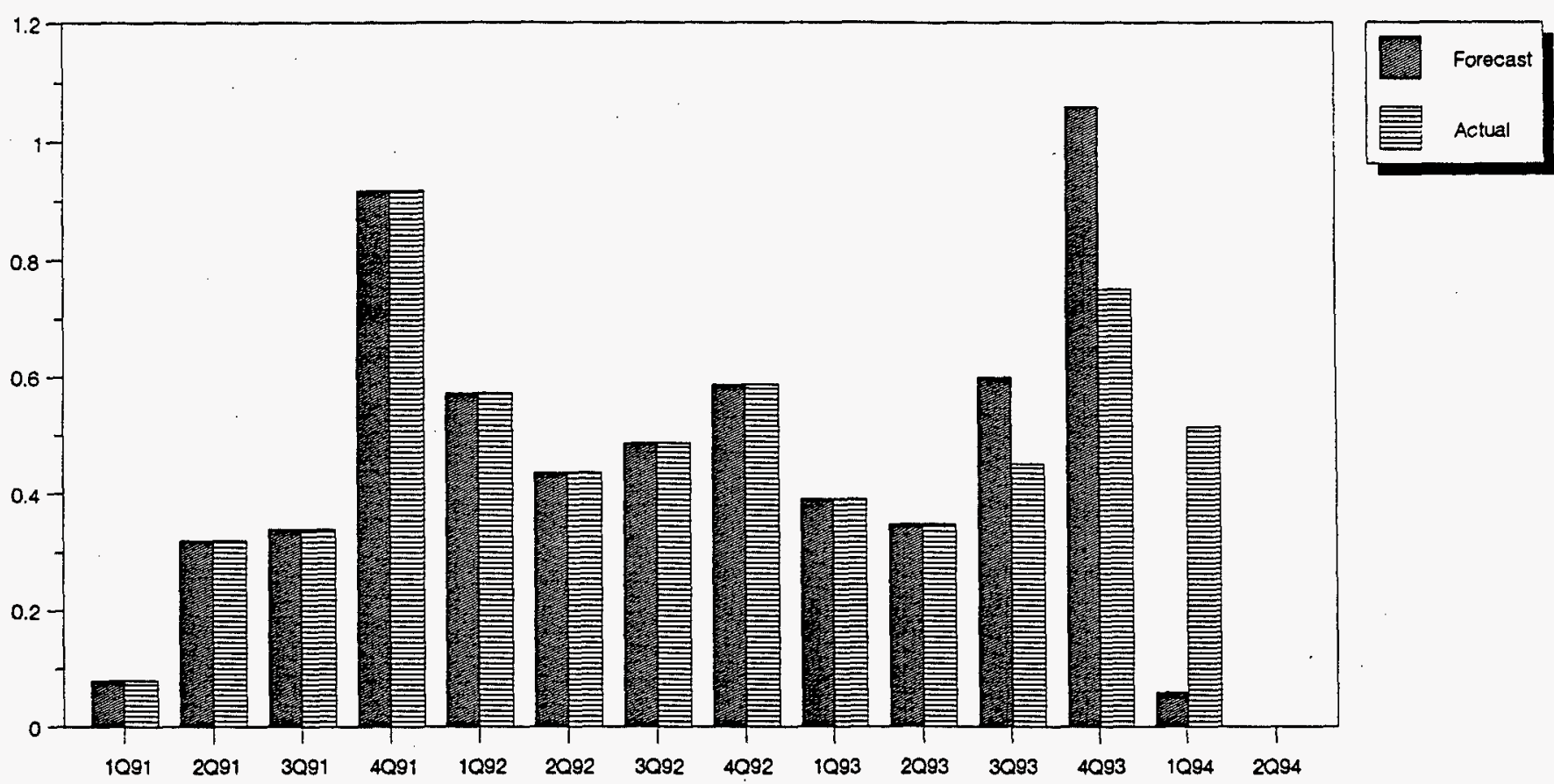

its

$1091 \quad 2091 \quad 3091$

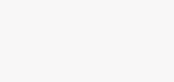

$-$

\begin{tabular}{|c|c|c|c|c|c|c|c|c|c|c|c|c|c|c|c|}
\hline & (in Millio & & & & & & & & & & & & & & \\
\hline & 1091 & 2091 & 3091 & 4091 & 1092 & 2092 & 3092 & 4092 & 1093 & 2093 & 3093 & 4093 & 1094 & 2094 & To-dato \\
\hline Forecast & 0.080 & 0.320 & 0.339 & 0.918 & 0.573 & 0.437 & 0.488 & 0.587 & 0.391 & 0.348 & 0.600 & 1.060 & 0.059 & 0.0 & 6.200 \\
\hline Actual & 0.080 & 0.320 & 0.339 & 0.918 & 0.573 & 0.437 & 0.488 & 0.587 & 0.391 & 0.348 & 0.451 & 0.752 & 0.515 & 0.0 & 6.200 \\
\hline
\end{tabular}


The following represents the financial status of the Tidd PFBC Demonstration Project - Phase III - 4th year, as of June 30, 1994.

\section{Expenditures}

Operations (Est. $\$ 12,457,000$ )

Funding Source

- USDOE Share of Cost Growth

- USDOE Cost Sharing

- OCDO Cash Contribution

- OPCO Coal Contribution

- ABBC Contribution

- B\&W Contribution

\section{$\$ 3,469,363 *$}

$(\$ 3,564,633) \$ 3,564,633$

$(\$ 3,192,360) \quad 0$

$(\$ 2,600,000)$

0

$(\$ 2,300,007)$

(\$ 400,000 )

(\$ 400,000)

Total Funding To-Date

$\$ 3,564,633$

Remaining Portion of Expenditures to be Recovered

$\$(95,270)$ 
Figure 5 is the 4th Year Operations Quarterly Actual and Projected Expenditures

TIDD PFBC DEMONSTRATION PLANT

QUARTERLY EXPENDITURES-4TH YEAR OPERATIONS

$\$ \quad$ (in Millions)

FORECAST VERSUS ACTUAL
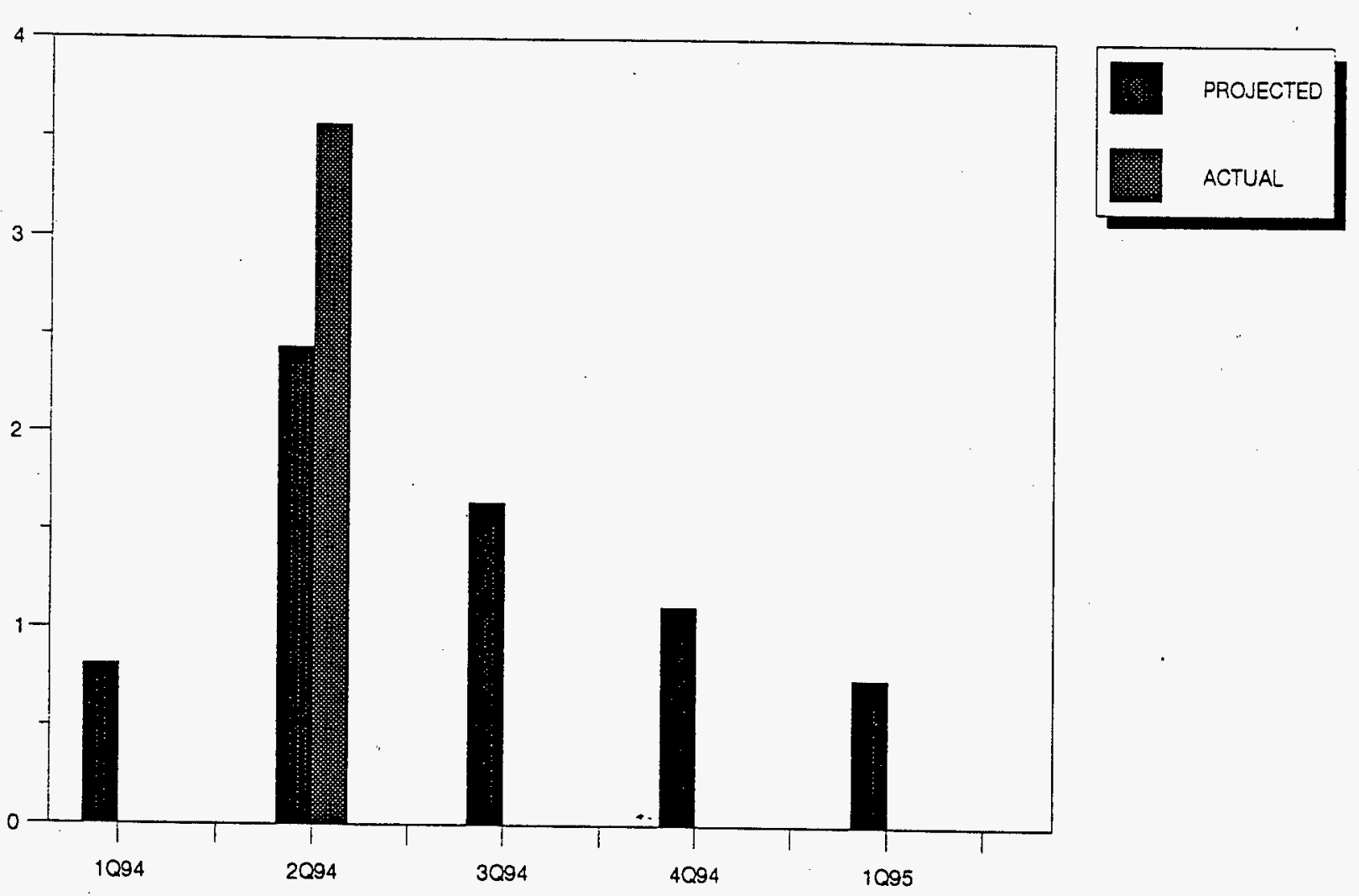

is: 
M97053807

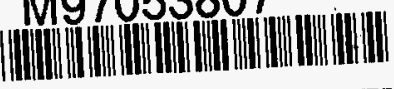

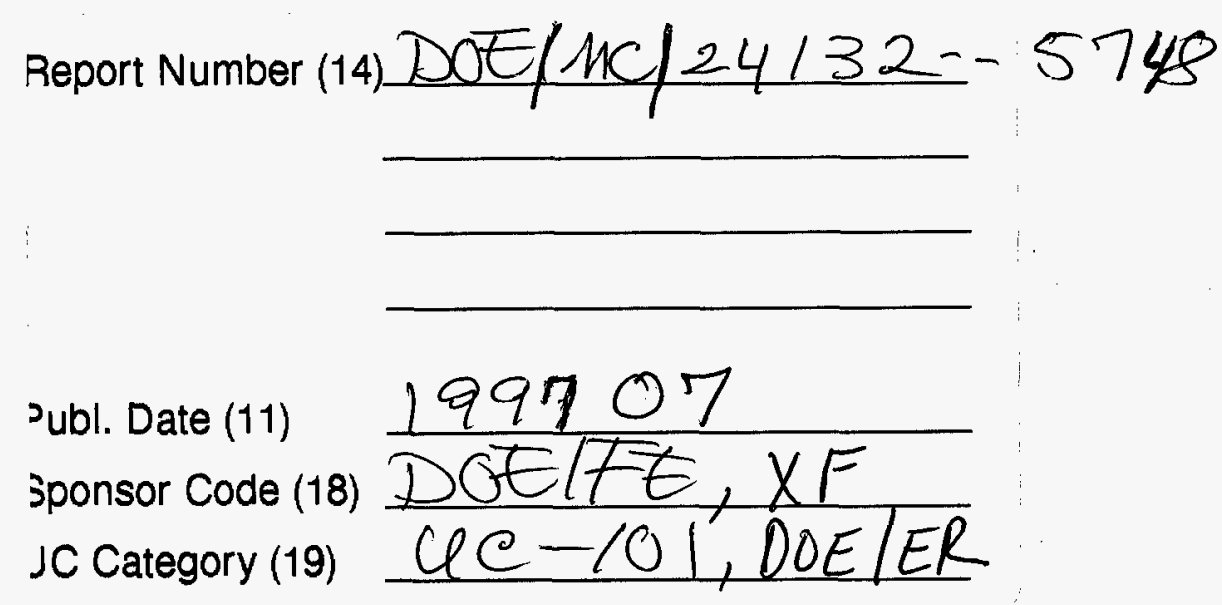

